テで実際に撮影しているのか.

答 あちろんアルミカセッテを実用しているのではな (2.

座長，全演者へ質問，被写体とフィルム間の支持体， グリッド等に CFRP を用いる多くの研究を報告して頂 いたが，そのために直接コントラストが良くなるのでは 無く，アクリル等の支持体を CFRP に変えることによ りX線の透過が良くなるため, 撮影電圧を下げることが でき二次的にコントラスト向上になっていると解䣋して 良いか。

答 338 席河村, 厚いアクリルでは散乱体として㗢く ため, 被写体が厚くなったのと同じに作用する点がある. 338席協同研究者, 東芝荒巻, 報告していない内容だが, 散乱線除去率を計ればアルそと CFRP が同じになるが， コントラストは CFRP 使用の方が良い結果となる。 こ の原因は不明だが何かの因子が有ると思うので今後続け て検討したい.

東芝鶴見病院, 蕗, CFRP 等の散乱線スペクトルを測 定したが，アルミとCFRPではアルミを透過したX線 の方が固くなっている. また今回の報告はすべて平行グ リッドでの結果のようであるが，私はクロスグリッドに して良い効果を得ている。

この演題群全部が被写体を透過して被写体の情報をむ つているX線を効率良くX線フィルムまたは I.I. の入力 螢光面に入射させようとするすので, 335から338席迄の 4 題が CFRP（炭素繊維強化樹脂）の利用研究で， 339 席はファイングリッド $(57$ 本 $/ \mathrm{cm})$ の効果についての研 究報告であった. CFRP の利用では全演者がその効果の 大きいととを認め，その効果を実用的にするためには， 被写体とフィルム等の間に介在するすべての物（天板, グリッド, カセッテ, 増感紙, 螢光体の支持体等）をX 線吸収の少ない物質に変える必要があると述べている. この方法はフィルム系等の感度上昇による場合と異なり， 粒状性の悪化など, 画質の悪化が無く，被写体からの画 像情報をより良く伝達するようにするものであるため， 被検者の被曝 X線量の低減と画質の向上が両立すること になる. とのように欠点の少ない方法であるから急速に 普及させて，診療の場で早く実用されるよう望む。ファ イングリッドについては，格子比を同じにして格子密度 を上げれば，格子の高さが低くなるので報告のような結 果が出るものと思われた. 質問に出たような配慮が必要 と思われる。

予稿集の訂正. 338 席16行目「マイクロデンシトメー タ・サクラ PDM-5・ユニオン MBM」と訂正. 同 339席
14 行目中間より「結果を図 2 ，図 3 ，図 4 亿示す。

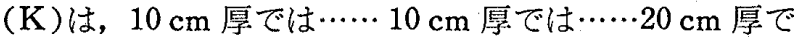
は $\mathrm{N}=34 」$ と訂正.

\section{CT-7 応用-3}

座長 矢仲重信（日立メディコ）

340. SOMATOM-2 の性能評価（その1）

信州大学医学部附属病院放射線部

○安藤 隆・矢野今朝人 上田 仁・丸山 清

〔目的〕SOMATOM-2 全身用 CT 装置設置時におけ る種々の性能テストを, 京都科学標本社製 CT テストフ テントムを使用して行ったので報告する.

〔結果】雑音は， $8 \mathrm{~mm}$ スライス，10秒スキャン, 460 $\mathrm{mAs}$ で 0.57\% (300 mm $\phi)$ であった. 画像の寸法依存 性でその均一性は，いずれも $2 \sigma$ 以内で良好であった。 位置依存性むシフト方向にて, CT 值の上昇が僅か見ら れたが無視できると思われる．高コントラスト分解能は 最高 $1.0 \mathrm{~mm}$ であった. 低コントラスト分解能は最高, $\mathrm{CT}$ 值の差 5 で約 $5 \mathrm{~mm}$ であった.ノイズおよび高コン トラスト分解能は，その装置の規格内に納った。これら を今後の装置の基準の目安とする.

\section{SOMATOM2 の性能評価（その 2)}

信州大学医学部附属病院放射線部 ○上田 仁・矢野今朝人 安藤 隆・丸山 清

〔目的〕SOMATOM2 の特性を把握するために，日 放医 CT 性能評価委員会の勧告に基づき, 空間分解能ス ライス厚等について検討を行った。また, 高感度検出器 （ミニテラーク）に扔ける被曝量の測定も行なっだ.

〔結果] (1)空間分解能においてはマトリックスが 256 ×256であるが原データを拡大するととによりかなり向 上した. (2)スライス厚，呮差が $\pm 0.25 \mathrm{~mm}$ であり公称 值どうりと思われた。（3)被曝線量は，日常 $230 \mathrm{mAs}$ の スキャンを行なうことで低線量撮影が可能と思われた。 以上の結果より当装置は臨床例においても彰断に適した 画像が得られ，定期的に整備チェックを行なうことでよ りよい画像が得られると思われる.

\section{2. 未熟児 CT 検査用クベースについて（第二報）}

神奈川県立とども医療センター

○中川敏夫・西尾誠示・藤生英夫 梅津幹夫・宮城哲夫・岡野滋樹

〔目的】クベース管理されている患者のCT 検査専用 のクベースを作成し実用化できたので最終報告をする. 